\title{
The Genetics of How Dogs Became Our Social Allies
}

Per Jensen, Mia E Persson, Dominic Wright, Martin Johnsson, Ann-Sofie Sundman and Lina S. V. Roth

\section{Journal Article}

\section{Tweet}

N.B.: When citing this work, cite the original article.

Original Publication:

Per Jensen, Mia E Persson, Dominic Wright, Martin Johnsson, Ann-Sofie Sundman and Lina S. V. Roth, The Genetics of How Dogs Became Our Social Allies, Current directions in psychological science (Print), 2016. 25(5), pp.334-338.

http://dx.doi.org/10.1177/0963721416657050

Copyright: Association for Psychological Science

http://www.psychologicalscience.org/

Postprint available at: Linköping University Electronic Press

http://urn.kb.se/resolve?urn=urn:nbn:se:liu:diva-131860

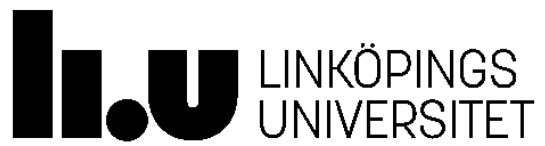




\section{The genetics of how dogs became our social allies}

Per Jensen*, Mia E Persson, Dominic Wright, Martin Johnsson, Ann-Sofie

Sundman, Lina S V Roth

Linköping University

*Corresponding author:

IFM Biology, AVIAN Behaviour Genomics and Physiology group

Linköping University

58183 Linköping

Sweden

E-mail:perje@ifm.liu.se 


\section{Abstract}

Dogs were domesticated from wolves about 15000 years ago and an important selection pressure (intentional or unintentional) has been their ability to communicate and cooperate with us. They show extensive human-directed sociability, which varies within as well as between breeds and which is not shared by ancestral wolves. Hence, dogs are potentially ideal models for studying the genetics of social behaviour. Here we review some recent research carried out by others and us on this subject. We present results showing that recent selection of different breed types can be used as a model system for investigating the genetic architecture of personalities. Furthermore, we review data showing that human-directed social behaviour is significantly related to a small number of genes, which have known connections to human social disorders such as autism and schizophrenia. We suggest that dogs are excellent study subjects for analyzing the evolution and genetics of social behaviour, and can serve as probes for human health and welfare.

\section{Keywords}

Genetics, social behaviour, canids, breed, welfare 
The onset of dog domestication about 15000 years ago (Wang et al., 2015) represents one of the most important events in human history. It preceded agriculture and the domestication of other animal species by about 5000 years and represents the largest (albeit unconscious) biological and genetic experiment in history. Indeed, already Darwin himself recognized the extensive power of domestication as a proof of principle for evolution.

Although there is no universal agreement concerning the exact location and commencement of dog domestication (Ding et al., 2011; Larson et al., 2012) it is clear that all dogs originate from a relatively limited number of individual grey wolves, Canis lupus, one of the most cooperative and social mammals on earth. Although the details of the domestication process are still open to research, the extensive sociability of the species is probably one important reason why wolves initially associated early with humans and would have made it comparatively easy for our ancestors to take control over their breeding - the fundamental hallmark of domestication. In doing so, it is likely that one trait was favoured strongly: the ability to cooperate with humans. Even though within-species social behaviour probably changed during domestication, selection for gene variants (alleles) favouring sociability across species are likely to have been intense.

\section{From phenotypic variation to genetics}

As a result of breeding, dogs have become the most variable mammalian species on the planet. While the smallest breeds reach an adult weight of less than $1 \mathrm{~kg}$, 
the largest grow to about $70 \mathrm{~kg}$. Colour, fur and shape vary within large boundaries, and yet there is no genetic reproductive isolation (as evidenced, for example by the popular hybrid "pomsky", a cross between the $20 \mathrm{~cm}$ high Pomeranian and the 50-60 cm husky). This variation is equally obvious with respect to behaviour. For example, some breeds instinctively attempt to herd (e.g., border collie, kelpie) and others are predisposed for fetching and carrying object (e.g, Labrador retriever, springer spaniel).

Since its genome was sequenced in 2005 (Lindblad-Toh et al., 2005) the dog has therefore become one of the most promising models for behaviour genetics (Hall and Wynne, 2012). By focusing on traits, which distinguishes breeds from each other or individuals within breeds, it is possible to reveal the underlying genetics of behavioural variation. For example, a gene called $C D H 2$ on the canine chromosome 7 has been found to be associated with compulsive-like behaviour in the Doberman Pinscher (Dodman et al., 2010).

\section{Domestication modified sociability}

During domestication dogs have developed unprecedented abilities for crossspecies understanding and communication. Here are a couple of examples of this as studied in numerous recent experiments:

Dogs excel in understanding human pointing and other ostensive cues (Hare et al., 2002). This includes gaze following and the ability to observe and act in accordance with their owners' attention focus (Virányi et al., 2004). Closely 
linked to this is the extensive ability of dogs to distinguish their own perspectives from that of humans (perhaps reflecting a primitive "theory of mind") (Maginnity and Grace, 2014). This allows them to adapt their behaviour according to their owner's attention, for example, by changing their actions according to whether they being watched or not by the owner in the same room (Kaminski et al., 2012). Closely related to this, many dogs are also remarkably able to identify emotional states of humans through our facial expressions (Müller et al., 2015).

Furthermore, dogs have an extraordinary comprehension of human spoken words (Pilley and Reid, 2011). In distinct contrast to wolves, dogs themselves have a large repertoire of various vocalizations, particularly variants of barking, which are used specifically for communication with humans (FeddersenPetersen, 2000; Pongrácz et al., 2005).

Dogs use all these social abilities primarily to cooperate with their owners and other humans. Tight bonds develop between dogs and their owners mediated by mutually increased levels of oxytocin, a neuropeptide related to social bonding in many species (Romero et al., 2014). Positive interactions are also associated with reduced levels of the stress hormone cortisol (Roth et al., 2016).

The extreme sociability of dogs is particularly evident when they are faced with a difficult problem. Wolves, even if socialized with humans from an early age, will mostly attempt to solve it themselves, while dogs will usually quickly turn to a nearby human using both eye contact and physical interactions (Udell, 2015). 
Investigating the genetic basis for this difference may also throw light on the genetics of human social behaviour - after all, we share most of our own genes and their functions with those of dogs (Lindblad-Toh et al., 2005) .

\section{Assessing dog behaviour}

In order to perform genetic analysis of behaviour one needs reliable and comprehensive phenotyping methods. In Sweden, the Dog Mentality Assessment (DMA) has been used for many years, and at this time more than 100000 dogs have taken the test (for details of the test, see, e.g., Svartberg and Forkman, 2002). Briefly, a trained observer scores the behaviour of the dogs in ten different sub-tests, assessing, e.g., fear, sociality and hunting motivation. Previous research has used this extensive database to calculate personality structures in different breeds as well as their heritabilities (the proportion of variation which is explained by genetic differences) (Saetre et al., 2006; Svartberg and Forkman, 2002), and observed, e.g., a major personality dimension "boldness", with a high heritability. We have found that the results of dogs in a very similar type of behavioural test reflect quality and quantity of maternal care received during the first weeks of life (Foyer et al., 2015; 2013), which may be related to genetic differences between mothers.

Using the large database from the DMA-test we now investigate the genetic architecture - i.e., frequencies of gene variants, how they are physically arranged in the genome and interact with each other - of complex personality types in dogs (Sundman et al, in press). We take advantage of the fact that some breeds 
have undergone a recent split into different types. For example, both Labrador and golden retrievers were split into a field and a conformation type where the former is bred mainly for hunting and retrieving abilities while the latter is bred for physical appearance. Since this selective breeding for well-specified traits started in homogenous populations of purebred retrievers we expect that genes affecting specifically the selected traits will stand out against the common background.

Results from more than 2500 dogs showed that the fundamental personality traits derived from the behaviour tests have significant heritabilities (Sundman et al, in press). Moreover, the behaviour differences between the two types are not consistent across breeds. For example, in Labradors the score for "curiosity" was higher in the conformation type while in golden retrievers the same score was higher in the field type. This indicates that the underlying genetic architecture for the behaviour traits is different in the two breeds, in spite of their close relatedness. The next step in this research line will be to genotype the dogs and use genome wide association methods to link different behaviour traits to specific DNA-sequences, a method that we have previously used in another context as described below.

\section{A specific test for dog-human sociability}

The DMA-test and other large-scale behaviour screenings lack details and rigour in the behaviour scoring methods and do not properly assess dog-human social interactions, and difficult phenotyping is in general a problem in the area of dog 
behavior genetics (van Rooy et al., 2014). Hence, to study this we use the "unsolvable problem paradigm", based on the propensity of dogs to seek human assistance. This is a variant of a commonly used test for similar purposes, for example by Udell et al. (2015). In our test version, dogs are presented with a simple apparatus where two lids can be opened to reveal a treat, while a third is fixed. The dogs are allowed to explore the apparatus freely and try to solve the task on their own. As they fail to open the third lid most of them will use various means to attract the attention of a human in the room, ranging from brief gazing with eye contact to physical interaction such as jumping at and pawing the person. From video recordings we score frequency and intensity of attention seeking behaviours as measures of the social propensity. This differentiates effectively dogs from wolves, and even if the propensity to interact with humans does develop with experience, it appears to have a strong genetic component as will be seen in the following.

\section{Genes for social behaviour in dogs and humans}

The test was applied to a sample of about 500 beagles, bred and kept at a kennel producing dogs for laboratory purposes (Persson et al., 2015). Here, environmental factors and human interactions were highly standardized during rearing and pedigrees well documented, allowing estimation of heritability. Females were more inclined to seek help by means of physical interactions with the human and the heritability assessment showed that $23 \%$ of the variation could be attributed to genetic differences. 
We further obtained DNA-samples from about 200 individuals. These were genotyped for more than 172000 genetic markers (positions in the genome where there is genetic variation), and we looked for associations between markers and the social behaviour (Persson et al, in press). This represents a socalled Genome Wide Association Study (GWAS), commonly used to associate, for example, disease phenotypes with specific genomic regions (see, e.g., Dodman et al., 2010). However, our experiment represents the first attempt to apply the method to find genes associated with domestication related behaviour in dogs.

We found a significant relationship between the degree of human contact in the problem-solving situation and two genomic regions on chromosome 26, including five possible associated genes. The two strongest candidates, based on the location in relation to the markers, are the genes SEZ6L and ARVCF. Interestingly, both have previously been associated with human social disorders. SEZ6L was recently linked to autism spectrum disorder (Chapman et al., 2015) and ARVCF has been associated with schizophrenia (Sim et al., 2012). Another strong candidate is the gene COMT, which has been widely studied in relation to social and emotional behaviour in humans (schizophrenia and "persistence" personality types). COMT produces an enzyme (catechol-0-methyltransferase) that degrades catecholamines post-synaptically. A particular mutation (called Val158Met) is important in this respect and the frequency of a similar mutation has been found to vary between different dog breeds (Masuda et al., 2004). Although no studies have been conducted on wolves in this respect, it is possible that these genes may have been important targets of selection during dog domestication. 


\section{Dogs as models for human behaviour?}

The strong similarities between dog and human behavioural phenotypes affected by the genes identified in our research emphasize the potential of using dogs as models for human social behaviour disorders, as suggested already by Overall (2000). It is tempting to see the parallel between, on one hand, the beagles refraining from interacting with humans and, on the other, humans with autism spectrum disorders.

Others have looked for associations between dog social behaviour and genes, which could be involved based on prior knowledge of their functions in humans. For example, due to its relatedness to mood and activity disorders in humans the tyrosine hydroxylase (TH) gene was suspected to be involved in similar behaviour variation in dogs (Kubinyi et al., 2012). German shepherd dogs were scored for behaviour corresponding to the human ADHD syndrome and a common variant of the gene was shown to be closely associated with the outcome.

Also the pituitary hormone oxytocin has attracted a large interest in relation to social behaviour. It is involved in attachment and sociability in a number of contexts across many species (Donaldson and Young, 2008). In dogs, it is closely associated with human-directed sociability (Romero et al., 2014). The oxytocin receptor gene has some well-investigated variants, which modify the effect of the hormone on social behaviour in humans (Feng et al., 2015), and similar variants 
in the same gene affect human-directed social behaviour in dogs (Kis et al., 2014). We therefore hypothesized in a recent experiment that this effect may be due to the receptor variants modulating the effect of the hormone. We administered oxytocin intranasally before presenting golden retrievers with the unsolvable problem as described above. Our preliminary findings (Persson et al, unpublished data) indicate that oxytocin does indeed increase sociability of the dogs and the effect is to some extent related to a common polymorphism (a gene variant) in the oxytocin receptor gene.

\section{Dogs as lithmus paper for human health}

During the 15000 years that have passed since humans domesticated the first wolves, dogs have shared our lives and in many places and times they have become family members. In various cultures, people have buried them as valued friends, often together with their owners, at least for the last 14000 years (Morey, 2006). Strikingly, in modern societies they tend to develop similar "western civilization-related" health problems as humans, such as obesity, diabetes, allergies and circulatory diseases (see e.g., German, 2006; Courtney Moore et al., 2011). Our research, together with that of other groups, indicates that also psychiatric disorders may share common mechanisms. Dogs could therefore potentially be probes for human health reflected by similar responses in dogs living in the same social and societal context.

In conclusion, dogs may not only be important keys to a deepened understanding of evolution and behaviour genetics, they may also serve as living models of our 
own health and welfare. Not a bad companion for scientists, or for humanity at large.

\section{Acknowledgements}

The research was funded by European Research Council, Advanced Grant 322206 GENEWELL. 


\section{References}

Chapman, N.H., Nato, A.Q., Bernier, R., Ankenman, K., Sohi, H., Munson, J., Patowary, A., Archer, M., Blue, E.M., Webb, S.J., Coon, H., Raskind, W.H., Brkanac, Z., Wijsman, E.M., 2015. Whole exome sequencing in extended families with autism spectrum disorder implicates four candidate genes. Hum. Genet. 134, 1055-1068. doi:10.1007/s00439-015-1585-y

Courtney Moore, M., Menon, R., Coate, K.C., Gannon, M., Smith, M.S., Farmer, B., Willliams, P.E., 2011. Diet-induced impaired glucose tolerance and gestational diabetes in the dog. J. Appl. Physiol. 110, 458-467.

Ding, Z.-L., Oskarsson, M., Ardalan, A., Angleby, H., Dahlgren, L.-G., Tepeli, C., Kirkness, E., Savolainen, P., Zhang, Y.P., 2011. Origins of domestic dog in Southern East Asia is supported by analysis of Y-chromosome DNA. Heredity 108, 507-514. doi:10.1038/hdy.2011.114

Dodman, N.H., Karlsson, E.K., Moon-Fanelli, A., Galdzicka, M., Perloski, M., Shuster, L., Lindblad-Toh, K., Ginns, E.I., 2010. A canine chromosome 7 locus confers compulsive disorder susceptibility. Mol. Psychiatry 15, 8-10. doi:10.1038/mp.2009.111

Donaldson, Z.R., Young, L.J., 2008. Oxytocin, Vasopressin, and the Neurogenetics of Sociality. Science 322, 900-904. doi:10.1126/science.1158668

Feddersen-Petersen, D.U., 2000. Vocalization of European wolves (Canis lupus lupus L.) and various dog breeds (Canis lupus f. fam.). Archiv fur Tierzucht.

Feng, C., Lori, A., Waldman, I.D., Binder, E.B., Haroon, E., Rilling, J.K., 2015. A common oxytocin receptor gene (OXTR) polymorphism modulates intranasal oxytocin effects on the neural response to social cooperation in humans. Genes Brain Behav 14, 516-525. doi:10.1111/gbb.12234

Foyer, P., Wilsson, E., Jensen, P., 2015. Levels of maternal care in dogs affect adult offspring temperament. Sci Rep 6, 1-8. doi:10.1038/srep19253

Foyer, P., Wilsson, E., Wright, D., Jensen, P., 2013. Early experiences modulate stress coping in a population of German shepherd dogs. Applied Animal Behaviour ... 146, 79-87.

German, A.J., 2006. The growing problem of obesity in dogs and cats. J. Nutr. 136, 1940S-1946S.

Hall, N.J., Wynne, C.D.L., 2012. The canid genome: behavioral geneticists' best friend? Genes, Brain and Behavior, 11: 889-902.

Hare, B., Brown, M., Williamson, C., Tomasello, M., 2002. The Domestication of Social Cognition in Dogs. Science 298, 1634-1636. doi:10.1126/science.1072702

Kaminski, J., Pitsch, A., Tomasello, M., 2012. Dogs steal in the dark. Anim Cogn 16, 385-394. doi:10.1007/s10071-012-0579-6

Kis, A., Bence, M., Lakatos, G., Pergel, E., Turcsán, B., Pluijmakers, J., Vas, J., Elek, Z., Brúder, I., Földi, L., Sasvari-Szekely, M., Miklósi, Á., Ronai, Z., Kubinyi, E., 2014. Oxytocin Receptor Gene Polymorphisms Are Associated with Human Directed Social Behavior in Dogs (Canis familiaris). PLoS ONE 9, e83993. doi:10.1371/journal.pone.0083993.t005

Kubinyi, E., Vas, J., Hejjas, K., Ronai, Z., Brúder, I., Turcsán, B., Sasvari-Szekely, M., Miklósi, Á., 2012. Polymorphism in the Tyrosine Hydroxylase (TH) Gene Is 
Associated with Activity-Impulsivity in German Shepherd Dogs. PLoS ONE 7, e30271. doi:10.1371/journal.pone.0030271.t002

Larson, G., Karlsson, E.K., Perri, A., Webster, M.T., Ho, S.Y.W., Peters, J., Stahl, P.W., Piper, P.J., Lingaas, F., Fredholm, M., Comstock, K.E., Modiano, J.F., Schelling, C., Agoulnik, A.I., Leegwater, P.A., Dobney, K., Vigne, J.D., Vila, C., Andersson, L., Lindblad-Toh, K., 2012. Rethinking dog domestication by integrating genetics, archeology, and biogeography. Proc. Natl. Acad. Sci. U.S.A. 109, 8878-8883. doi:10.1073/pnas.1203005109

Lindblad-Toh, K., Wade, C.M., Mikkelsen, T.S., Karlsson, E.K., Jaffe, D.B., Kamal, M., Clamp, M., Chang, J.L., Kulbokas, E.J., Zody, M.C., Mauceli, E., Xie, X., Breen, M., Wayne, R.K., Ostrander, E.A., Ponting, C.P., Galibert, F., Smith, D.R., deJong, P.J., Kirkness, E., Alvarez, P., Biagi, T., Brockman, W., Butler, J., Chin, C.-W., Cook, A., Cuff, J., Daly, M.J., DeCaprio, D., Gnerre, S., Grabherr, M., Kellis, M., Kleber, M., Bardeleben, C., Goodstadt, L., Heger, A., Hitte, C., Kim, L., Koepfli, K.-P., Parker, H.G., Pollinger, J.P., Searle, S.M.J., Sutter, N.B., Thomas, R., Webber, C., Baldwin, J., Abebe, A., Abouelleil, A., Aftuck, L., Ait-zahra, M., Aldredge, T., Allen, N., An, P., Anderson, S., Antoine, C., Arachchi, H., Aslam, A., Ayotte, L., Bachantsang, P., Barry, A., Bayul, T., Benamara, M., Berlin, A., Bessette, D., Blitshteyn, B., Bloom, T., Blye, J., Boguslavskiy, L., Bonnet, C., Boukhgalter, B., Brown, A., Cahill, P., Calixte, N., Camarata, J., Cheshatsang, Y., Chu, J., Citroen, M., Collymore, A., Cooke, P., Dawoe, T., Daza, R., Decktor, K., DeGray, S., Dhargay, N., Dooley, K., Dooley, K., Dorje, P., Dorjee, K., Dorris, L., Duffey, N., Dupes, A., Egbiremolen, O., Elong, R., Falk, J., Farina, A., Faro, S., Ferguson, D., Ferreira, P., Fisher, S., FitzGerald, M., Foley, K., Foley, C., Franke, A., Friedrich, D., Gage, D., Garber, M., Gearin, G., Giannoukos, G., Goode, T., Goyette, A., Graham, J., Grandbois, E., Gyaltsen, K., Hafez, N., Hagopian, D., Hagos, B., Hall, J., Healy, C., Hegarty, R., Honan, T., Horn, A., Houde, N., Hughes, L., Hunnicutt, L., Husby, M., Jester, B., Jones, C., Kamat, A., Kanga, B., Kells, C., Khazanovich, D., Kieu, A.C., Kisner, P., Kumar, M., Lance, K., Landers, T., Lara, M., Lee, W., Leger, J.-P., Lennon, N., Leuper, L., LeVine, S., Liu, J., Liu, X., Lokyitsang, Y., Lokyitsang, T., Lui, A., Macdonald, J., Major, J., Marabella, R., Maru, K., Matthews, C., McDonough, S., Mehta, T., Meldrim, J., Melnikov, A., Meneus, L., Mihalev, A., Mihova, T., Miller, K., Mittelman, R., Mlenga, V., Mulrain, L., Munson, G., Navidi, A., Naylor, J., Nguyen, T., Nguyen, N., Nguyen, C., Nguyen, T., Nicol, R., Norbu, N., Norbu, C., Novod, N., Nyima, T., Olandt, P., O'Neill, B., O'Neill, K., Osman, S., Oyono, L., Patti, C., Perrin, D., Phunkhang, P., Pierre, F., Priest, M., Rachupka, A., Raghuraman, S., Rameau, R., Ray, V., Raymond, C., Rege, F., Rise, C., Rogers, J., Rogov, P., Sahalie, J., Settipalli, S., Sharpe, T., Shea, T., Sheehan, M., Sherpa, N., Shi, J., Shih, D., Sloan, J., Smith, C., Sparrow, T., Stalker, J., Stange-Thomann, N., Stavropoulos, S., Stone, C., Stone, S., Sykes, S., Tchuinga, P., Tenzing, P., Tesfaye, S., Thoulutsang, D., Thoulutsang, Y., Topham, K., Topping, I., Tsamla, T., Vassiliev, H., Venkataraman, V., Vo, A., Wangchuk, T., Wangdi, T., Weiand, M., Wilkinson, J., Wilson, A., Yadav, S., Yang, S., Yang, X., Young, G., Yu, Q., Zainoun, J., Zembek, L., Zimmer, A., Lander, E.S., 2005. Genome sequence, comparative analysis and haplotype structure of the domestic dog. Nature 438, 803-819. doi:10.1038/nature04338

Maginnity, M.E., Grace, R.C., 2014. Visual perspective taking by dogs (Canis familiaris) in a Guesser-Knower task: evidence for a canine theory of mind? Anim Cogn 17, 1375-1392. doi:10.1007/s10071-014-0773-9 
Masuda, K., Hashizume, C., Kikusui, T., Takeuchi, Y., Mori, Y., 2004. Breed differences in genotype and allele frequency of catechol 0-methyltransferase gene polymorphic regions in dogs. J. Vet. Med. Sci. 66, 183-187. doi:10.1292/jvms.66.183

Morey, D.F., 2006. Burying key evidence: the social bond between dogs and people. Journal of Archaeological Science 33, 158-175. doi:10.1016/j.jas.2005.07.009

Müller, C.A., Schmitt, K., Barber, A.L.A., Huber, L., 2015. Dogs Can Discriminate Emotional Expressions of Human Faces. CURBIO 25, 1-6. doi:10.1016/j.cub.2014.12.055

Overall, K.L. 2000. Natural animal models of human psychiatric conditions: assessment of mechanism and validity. Prog. Neuro-Psychophamacol. \& Biol. Psychiat. 24, 727-726.

Persson, M.E., Roth, L.S.V., Johnsson, M., Wright, D., Jensen, P., 2015. Humandirected social behaviour in dogs shows significant heritability. Genes Brain Behav 14, 337-344. doi:10.1111/gbb.12194

Persson, M.E., Wright, D., Roth, L.S.V., Batakis, P., Jensen, P. 2016. Genes associated with interspecies communication in dogs are also related to human social disorders. Scientific Reports, in press.

Pilley, J.W., Reid, A.K., 2011. Border collie comprehends object names as verbal referents. Behavioural Processes 86, 184-195. doi:10.1016/j.beproc.2010.11.007

Pongrácz, P., Molnár, C., Miklósi, Á., Csányi, V., 2005. Human Listeners Are Able to Classify Dog (Canis familiaris) Barks Recorded in Different Situations. Journal of Comparative Psychology 119, 136-144. doi:10.1037/07357036.119.2.136

Romero, T., Nagasawa, M., Mogi, K., Hasegawa, T., Kikusui, T., 2014. Oxytocin promotes social bonding in dogs. Proc. Natl. Acad. Sci. U.S.A. 111, 9085-9090. doi:10.1073/pnas.1322868111

Roth, L.S.V., Faresjö, Å., Theodorsson, E., Jensen, P., 2016. Hair cortisol varies with season and lifestyle and relates to human interactions in German shepherd dogs. Sci Rep 6, 19631. doi:10.1038/srep19631

van Rooy, D., Arnott, E.R., Early, J.B., McGreevy, P. Wade, C.M., 2014. Holding back the genes: limitations of research into canine behavioural genetics. Canine Genetics and Epidemiology 1, 7.

Saetre, P., Strandberg, E., Sundgren, P.E., Pettersson, U., Jazin, E., Bergstrom, T.F., 2006. The genetic contribution to canine personality. Genes Brain Behav 5, 240-248. doi:10.1111/j.1601-183X.2005.00155.X

Sim, K., Chan, W.-Y., Woon, P.-S., Low, H.-Q., Lim, L., Yang, G.-L., Lee, J., Chong, S.A., Sitoh, Y.-Y., Chan, Y.H., Liu, J., Tan, E.C., Williams, H., Nowinski, W.L., 2012. ARVCF genetic influences on neurocognitive and neuroanatomical intermediate phenotypes in Chinese patients with schizophrenia. J Clin Psychiatry 73, 320-326. doi:10.4088/JCP.10m06491

Svartberg, K., Forkman, B., 2002. Personality traits in the domestic dog (Canis familiaris). Applied Animal Behaviour Science 79, 133-155. doi:10.1016/S0168-1591(02)00121-1

Sundman, A-S., Johnsson, M., Wright, D., Jensen, P., 2016. Similar recent selection criteria associated with different behavioural effects in two dog breeds. In press, Genes, Brain and Behavior. 
Udell, M.A.R., 2015. When dogs look back: inhibition of independent problemsolving behaviour in domestic dogs (Canis lupus familiaris) compared with wolves (Canis lupus). Biology Letters 11, 20150489-479.

doi:10.1098/rsbl.2015.0489

Virányi, Z., Topál, J., Gácsi, M., Miklósi, Á., Csányi, V., 2004. Dogs respond appropriately to cues of humans' attentional focus. Behavioural Processes 66, 161-172. doi:10.1016/j.beproc.2004.01.012

Wang, G.-D., Zhai, W., Yang, H.-C., Wang, L., Zhong, L., Liu, Y.-H., Fan, R.-X., Yin, T.T., Zhu, C.-L., Poyarkov, A.D., Irwin, D.M., Hytönen, M.K., Lohi, H., Wu, C.-I., Savolainen, P., Zhang, Y.-P., 2015. Out of southern East Asia: the natural history of domestic dogs across the world. Cell Res. doi:10.1038/cr.2015.147 